\title{
The Influence Of Women Leaders And Their Leadership Style On Employee Engagement Through Talent Management As Mediating Variable
}

\author{
Dwi Putra Budi Setia ${ }^{1}$, Muhammad Romadhona ${ }^{2}$, Nurul Almy Firdausi ${ }^{3}$, \\ Tengku Mohd. Khairal Abdullah ${ }^{4}$ \\ 1,2,3,4 Business Management Program, Management Department, Binus Business SchoolMaster Program \\ Bina Nusantara University, Jakarta, Indonesia, 11480 \\ Email:1dwiputrabs66@gmail.com, ${ }^{2}$ muhromadhona@yahoo.com, ${ }^{3}$ nurulalmy85@gmail.com, \\ 4 tabdullah@binus.edu
}

\begin{abstract}
This research aims to investigate the impact of transformational \& transactional leadership style towards employee engagement mediated by talent management practices among subordinates with woman as their direct superiors. As the research was conducted during pandemic Covid-19, questionnaires were distributed through online. The method of purposive sampling was adopted to make sure that certain criteria was met before the respondents were deemed to be eligible in filling up the questionnaires. In the end, 117 questionnaires were returned, in which 64\% came from manufacturing and mineral industries (majority in oil and gas), while another $36 \%$ came from service industries (majority from public sector and trading). The analysis of multiple regression was performed towards the data in addition to use the mediation analysis proposed by Baron \& Kenny. The study found that both leadership style was indeed practiced by women leaders. However, results suggested that partial mediation exists in the relationship between transformational leadership style towards employee engagement. While full mediation was supported in the relationship between transactional leadership style towards employee engagement.
\end{abstract}

Keywords - Women Leadership, Transformational Leadership, Transactional Leadership, Talent Management Practices, Employee Engagement

\section{INTRODUCTION}

Promoting women on leadership positions have become more and more essential over the past decade. This is driven by continued gender inequity being reported in work and society (Smith and Suby-Long, 2019). Countries in Europe (Italy, France) have established mandatory quota for women in leadership position, while other countries (Australia, U.K) have included recommendation on women directorships to its corporate governance best practices (Chapple \&Humprey 2014). In Indonesia, there is no mandatory quota nor formal recommendation for women directorships, despite of economic and social benefits they can provide. McKinsey (2018) reported that $\$ 135$ billion of additional GDP in 2025 could be added to the economics of Indonesia by advancing women's equality, including in leadership role. Women are still under-represented in leadership positions with only $20 \%$ of them in middle management position and only $5 \%$ as CEO in Indonesia (McKinsey, 2018).

The women under-representation is also reflected in studies, with only less than $5 \%$ of leadership topics in Indonesia Research Databases (Neliti, Garuda) cover women leadership aspects. In western countries, multiple literatures related to women leadership aspects have been studied, with many stating unique quality and attributes, compared to men leadership (Eagly, 2013; Baker, 2014). Women leaders and their leadership style often lead to specific performance outcomes and organizational culture within groups (Parveen and Tariq, 2014; Pasaribu, 2017). One of the performance outcomes that is heavily connected to leadership style is employee engagement (Hansen, Byrne, \&Kiersch, 2013). Employee engagement can be defined as psychological states relating to spirit, absorption, and dedication to their work (Cahill etal., 2015). For this reason, researchers have continuously studied how employees are engaged when led by women (Gallup, 2016).

Women are perceived as less agency and greater communion compared to men (Vongalis-Macrow, 2016), considered as more caring, collegial, and social (Bruckmüller\&Branscombe, 2010), and are active listeners, emotionally connected, show motherly instincts and interested in relational exchanges (Fernandes \& Cabral-Cardoso, 2003). These traits are mostly seen in elements of transformational leadership style (Eagly, Johannesen-Schmidt, \& Van Engen, 2003; Koenig et al., 2011). Some researchers even label transformational leadership style as "feminine leadership style" (Carless, 1998; Chao, 2011). However, women leaders often demonstrate different leadership style and different traits on different environment, such as male-dominated environment where women are perceived to be more assertive and autocratic (Sharif, 2018). How women leaders enact their leadership style is also dependent on socio-cultural environment (Gipson etal., 2017). Further research also found that women try to achieve individual success in a men-dominated environment by shifting to the masculine approach and distancing themselves from other women (Ders, van Laar, \&Ellemers, 2016). 
Those contradictions on how women leader's traits and their leadership style perceived thus lead to question how women leaders actually engage with their subordinates. In connection to this, many researchers explored impacts of leadership styles towards employee engagement (Sadeli, 2012; Hansen, Byrne, \&Kiersch, 2013; Popli\& Rizvi, 2016; Sinaga, 2017), where it was found that both transactional and transformational leadership style has a positive relation with employee engagement (Sadeli, 2012; Popli\& Rizvi, 2016). Several research have found the linkage between leadership influence and employee engagement are mediated by talent management process (Ashton and Morton, 2005; Federmann, 2009; Schiemann, 2009; Sadeli, 2012), they also discovered that organizations implementing talent management practices tend to increase engagement.Nevertheless, limited number ofresearcheshave included leaders' gender into consideration, specifically women leadership impact on employee engagement.

Based on previous insights from literatures, there is obvious gap on women leadership researches in Indonesia. Issues related to how women leaders demonstrate their style and how they affect employee engagement are far from being resolved. Hence, the research objective of this paper is to find out how the leadership style demonstrated by women leaders influence employee engagement through talent management practice as mediating variable.

\section{LITERATURE REVIEW}

\section{a. Women Leaders}

It has been known for decades that gender stereotyping sees men leaders as more agency (ambitious, assertive, and competitive) than women leaders (Rudmanet al., 2012). According to Social Role Theory, gender stereotypes came from women's traditional role as housemakers and men's traditional role as the leader and head of the family (Eagly\&Diekman, 2000). This stereotyping leads to misperception of women leaders' capability and capacity, especially during the performance evaluation, showing women leaders are rated less favorably compared to men leaders (Lyness and Heilman, 2006).

Despite the stereotypes, Gipson (2017) suggested that there is actually lack of significant difference in style and performance (contribution) between men and women. According to Gipson, while there are differences between men and women leadership style, these differences do not result in a clear advantage of either gender across contexts. Furthermore, Pasaribu (2017) added that gender diversity in companies do not necessarily have significant influence on firm performance. Johnson et al. (2008) suggested that women leaders are actually seen as more effective when they show both strength (masculinity) and sensitivity (feminine) and will be perceived as inefficient leaders if they only show strength or sensitivity.

Nevertheless, Shinbrot et al. (2019) posited, even though men and women can have similar contributions as leaders, women are perceived to have uniquely grounded perspectives and novel approaches. One of the domains where women leaders can thrive is in the area of when subordinate need fulfilment and attention. This mother-like behavior improves the mood and the moral of subordinates (Mojza et al., 2011). Additionally, Rosener (1990) stated that the behaviors that define women leadership style come naturally. Rosener added that women are expected to be mothers, wives and stereotyped to certain role such as nurses and office admins. In all these roles, they are supposedly supportive, understanding, and provide service to others.

\section{b. $\quad$ Talent Management}

Talent management is associated with the systematic identification of positions which are key to the organization's competitive advantage sustainably over time(Collings and Mellahi, 2009). In the exclusive philosophy of talent management, some proportion of an organization's employees are seen as the organization's "talent" (Stahl et al., 2012) and managed as a strategic resource of the firm, as they hold some form of valued human capital. Talent is critical because it is the role of a Human Resourcefunction to manage everyone to high performance (Buckingham \& Vosburgh, 2001; Walker \&Larocco, 2002).

Qadir (2019) explained that gender-biased talent management activities have a detrimental effect on women managers 'progression. Talent management should be initiated by leaders in order to understand what key factor attract high potential in organization, build organizational competence/ capability and develop pools to ensure succession (Sadeli, 2012). Furthermore, talent management practices will promote more committed and engaged employees to produce maximum advantages for an organization (Mohammed, 2015).

When leaders and the organization are greatly concern on talent management practices, employees feel more valued, recognized and appreciated, thus will motivate employees to contribute to the organization. Davies \& Davies (2010) claimed talented employees need to be given affirmation and that their inputs matter for the organization or company. The theoretical ground is based on the social exchange theory, where employees are morally bound to engage as a return of resources they receive from their organization (Saks, 2006; Rothmann, 2016; Saks 2019). The study by Sadeli (2012), discovered that leaders implementing talent management 
practices tend to increase engagement. Research of Budiana et al. (2019) showed that the strategy of talent managementin increasing employee engagement of those from the talent pool is carried out through a two-stage monitoring engagement strategy model, in which each stage includes strategies for talent acquisition, talent development, and talent retention.

\section{Hypothesis 1, H1: “Talent Management Practices" positively influence "Employee Engagement”}

\section{c. Transformational Leadership}

Bass (1985) explained that Transformational leadership emphasize motivation development and prioritize individualized consideration. From leaders-member exchange theory point of view, transformational leadership behavior puts close and friendlier working relationship and is based on communality and group loyalty (Erturk, 2007). Additionally, it is also stated that Transformational Leadership focus on developing trust in the followerleader relationship and able to motivate the followers by showing the attribute of self-sacrificing leader (De Cremer and Van Knippengberg, 2005).

From gender's association perspectives, either Men or Women can demonstrate transformational leadership style but it matchesbetter to natural behavior of Women (Raes et al., 2013). These natural behavioral traits such as supportive, understanding, and socialization are also part of Transformational Leadership Behavior (Vinkenburget al., 2011). Interestingly, the study conducted by Ayman et al. (2009) suggested that the more female leaders associate to transformational leadership style, the less effectiveness score they received from their male subordinates (but not female). That means, women leaders are perceived differently when demonstrating leadership behaviors that was thought to be effective (Cuadrado et al., 2012; Eagly, 2013).

Study in particular byKim et al., (2015), demonstrated findings that transformational leadership exerts a positive effect on organizational commitment via the talent management ability of leaders. Kim et al. explained that transformational leaders try to increase subordinate's awareness of what is right and important and to motivate subordinates to perform beyond expectations. The basic logic for the proposed model is the emphasis on the strategic importance of the transformational leadership behavior in determining the success of the organization through talented and engaged human capital (Sadeli, 2012). Another research also mentioned that transformational leadership behavioris manifested on developing capabilities and competencies of subordinates (Rosette and Tost, 2010)

\section{Hypothesis 2, H2: "Transformational Leadership" positively influence "Talent Management Practices"}

\section{d. Transactional Leadership}

Bass (1985), explained that transactional leadership emphasizes exchange system between leadersmembers i.e. give rewards or discipline according to the performance or often called contingent rewards.Transactional leadership often seen as more unconstructive compared to transformational leadership (Sadeli, 2012). Rowold and Schlotz (2009) from their research concluded that transactional leadership leads to higher stress level on employee within governmental organizations. However, a leader might not be able to lead and influence the group effectively with no transactional leadership behavior at all (Lowe, Kroeck, \&Sivasubramaniam, 1996).

For example, Sharif (2018) found that often transactional leadership style is adopted by women leaders when facing resistance from subordinates or when being pushed as minority in a working environment dominated by male. Sharif (2018) further addedthat when women leaders had no choice and forced to exert power in this type of environment or situation, they shifted their leadership behavior to be more masculine and transactional. In general situation, women leaders are also expected to show transactional-like behavior (such as agentic and exerting power to control goals) while remaining sensitive in order to be perceived as effecitve leader (Johnson et al., 2008). Lastly, it is necessary to mentioned that Burns (1978) suggested that transactional and transformational leadership behaviors are mutually exclusive, which means a leader can only either be transactional or transformational at one specific time / situation. So, at one time / situation a leader can demonstrate transformational leadership style and on another time / another situation the leader can demonstrate transactional leadership style, but not both leadership style at the same time.

One study in particular bySinaga(2017), demonstrated that transactional leadership have a significant effect on talent management practices. This study (Sinaga, 2017) explained the role of transactional leadership has a very positive impact on increasing employee involvement, where leaders can be called an extension of the Human Resource Division and company functions in recognizing the ability of workers and developing them according to organization / company needs. In 2015, Kim et al. observed that leaders possess transactional leadership tend to build rewarding and transactional relationship with their subordinates. Thus, Kim et al. explained that their experience, aptitude, ability and motivation are supposed to be stimulated by transactional leadership style. Another example, transactional leadership might influence talent management practices in 
predictable environments, risk avoidance mind-set, collectivism culture, and strict-policy organization (Bass, 1985; Sharif, 2018)

\section{Hypothesis 3, H3: “Transactional Leadership" positively influence "Talent Management Practices"}

\section{e. Employee Engagement}

Schaufeli et al. (2002) defined engagement "as a positive, fulfilling, work-related state of mind that is characterized by vigor, dedication, and absorption" (p. 74). According to Noe et al. (2015), employee engagement itself "refers to the degree to which employees are fully involved in their work and the strength of their commitment to their job and the company", p.23. This emotional commitment creates an extent much more than what the employees are required to do, but what they are willing to do as an extra role and voluntary behavior. Employee engagement has been an issue which concerns many organizations and companies as part of managing their human resources (Sorenson, 2013).

Aspects in determining how an employee engages well in anorganization and company have been explored by researchers. Bedarkar\&Pandita (2014) identified that communications, work life balance and leadership are some factors that drives employee engagement. Kahn (1990) suggested that employee engagement is promoted by the advancement of three psychological characters: meaningfulness, availability and safety, who also purpose that leaders have an important role in fostering employee engagement. Kahn's research was strengthened by May et al. (2004) where it was found that these psychological characters have direct impact to employee engagement.Leadership style ishighly perceived to influence employee's engagement, where a certain style may work best in a particular condition (Popli\& Rizvi, 2016).

\section{Hypothesis 4, H4: "Transactional Leadership" positivelyinfluence "Employee Engagement" through mediation of "Talent Management Practices" \\ Hypothesis 5, H5: "Transactional Leadership" positively influence "Employee Engagement" through mediation of "Talent Management Practices"}

Based on the above discussions and summaries from previous literature, variables and how it interacts can be pictured as follows:

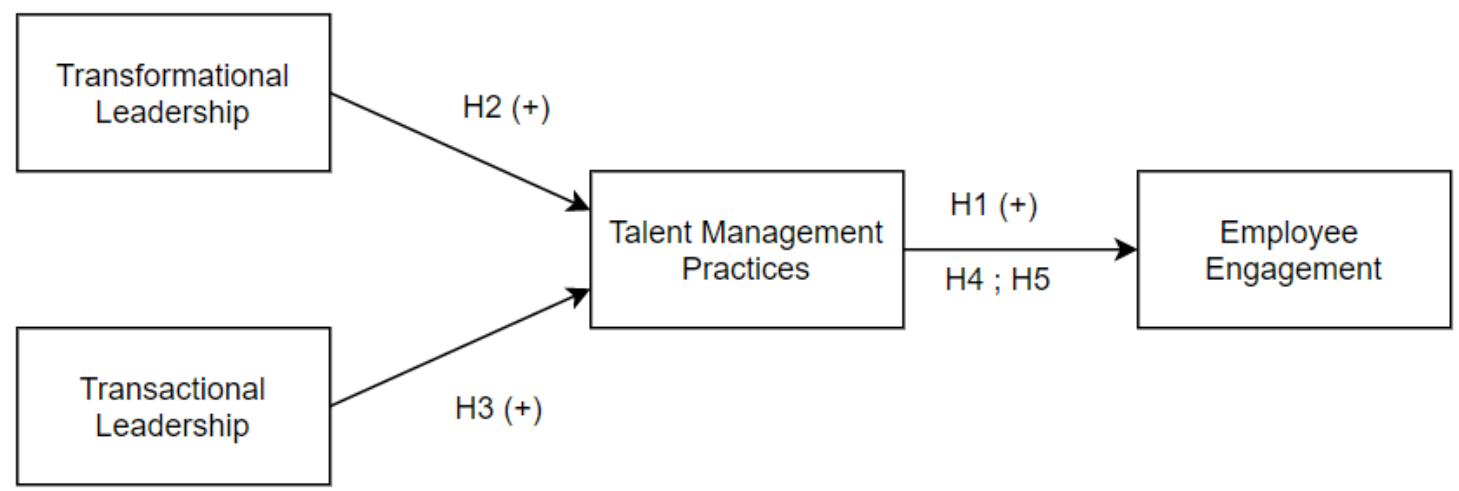

Figure.1 Theoretical Framework

As shown above, the theoretical framework will be used to evaluate how leadership style impact employee engagement mediated by talent management practices. In the context of this study, the frameworks will be used in an organization / group led by women.

Detailed assessment on the theoretical framework can be found on preceding studies concluded that leadership need mediating variable in order to influence employee with regards to employee engagement (Schaufeli, 2002; Saks, 2006; Sadeli, 2012; Sinaga, 2017)

\section{METHODOLOGY\& DATA COLLECTION}

The data collected for this study was conducted byaself-administered online questionnaire with a 6-point Likert scalewhere purposive sampling methodwas used based on the contacts of employees available to fit the criteria. This sampling and data collection method is chosen because it is more effective for the researchers to collect data in terms of time constraints, cost-effectivity, and convenience. The sample respondents had to be employees who are currently working in a company or institution based in Indonesia and being led directly by a female leader. 
In order to collectthe samples, we optimized different channels. We listedall of the community pages, social media groups, colleague networking and any organizations related, and requested their help in sharing the link of our research to their e-mail lists, forums, instant messaging groups, Facebook pages,and LinkedIn pages. Our questionnaire link had continuously circulated among different groups of the community at large, hence gain more online respondents in participating to fill in the survey.

The questionnaire was conducted in Bahasa Indonesia and consists of 38 questions to measure each variable. For measuring employee engagement, we adapt questions based on the research conducted by Saks (2006) which was also adapted by Sadeli (2012) and Sinaga (2017), where respondents were measured from job engagement dimension and organizational engagement dimension. Leadership styles are measured by adapting Bass \& Avolio (1993) Multifactor Leadership Questionnaire (MLQ), focusing on Transformational Leadership (Idealized influence, Intelectual stimulation, Individual consideration and Inspirational motivation dimensions) and Transactional Leadership (Reward achievement, Active management by exception, and passive management by exception). Talent management practices are measured based on approaches studied by previous researchers:Sadeli (2012) and Sinaga (2017) conducted the questions based on three dimensions: performance management, people development and succession planning.

The software being used for data analysis was SPSS and multiple regression analysis were applied to test the hypotheses. Tests of outliers, validity \& reliability and multivariate assumptions on normality, heteroscedasticity, linearity \& multi-collinearity were performed. Results showed no significant deviations from normality.

\section{RESULTS\& DISCUSSIONS}

The questionnaire was distributed between 28th July to17thSeptember 2020, during the COVID-19 Pandemic. There were 130 respondents who provided feedback, but 13 responseswere not included in our research because 11 respondents did not fulfil certaincriteriaof being led by a female leader and 2 respondents were classified as an outlier data based on univariate and multivariate test, thus only 117 respondents could be used for this research.Out of 117 respondents, $56 \%$ were female and $44 \%$ were male, composing of mostly between age 30 years old and under.Based on the type of industry, $64 \%$ of the respondents worked in the manufacturing and mineral industries (majority in oil\& gas) whereas $36 \%$ worked in the service industries (majority from public sector \& trading).

The validity and reliability of the data was tested and analyzed using factor analysis. Only one indicator was being eliminated and the rests showed significant factor loading of more than 0.5 (Hair et al., 2014), with Cronbach Alpha reported more than 0.7 .

Then conducted thehypotheses test using path analysis and analyzed the mediating effect.The mediating effect of Talent Management Practices was tested using the three-step procedure proposed by Baron and Kenny (1986). The testsresulted positive significance for Talent Management to Employee Engagement (H1), Transformation Leadership to Talent Management (H2), and Transactional Leadership to Talent Management (H3). For direct relations between Transformational Leadership to Employee Engagement the results were also positive and have significant effect, however for Transactional Leadership to Employee Engagement displayed a negative and insignificant effect. Details of each path is shown in Figure 2.

Figure 2. Structure Model Results 


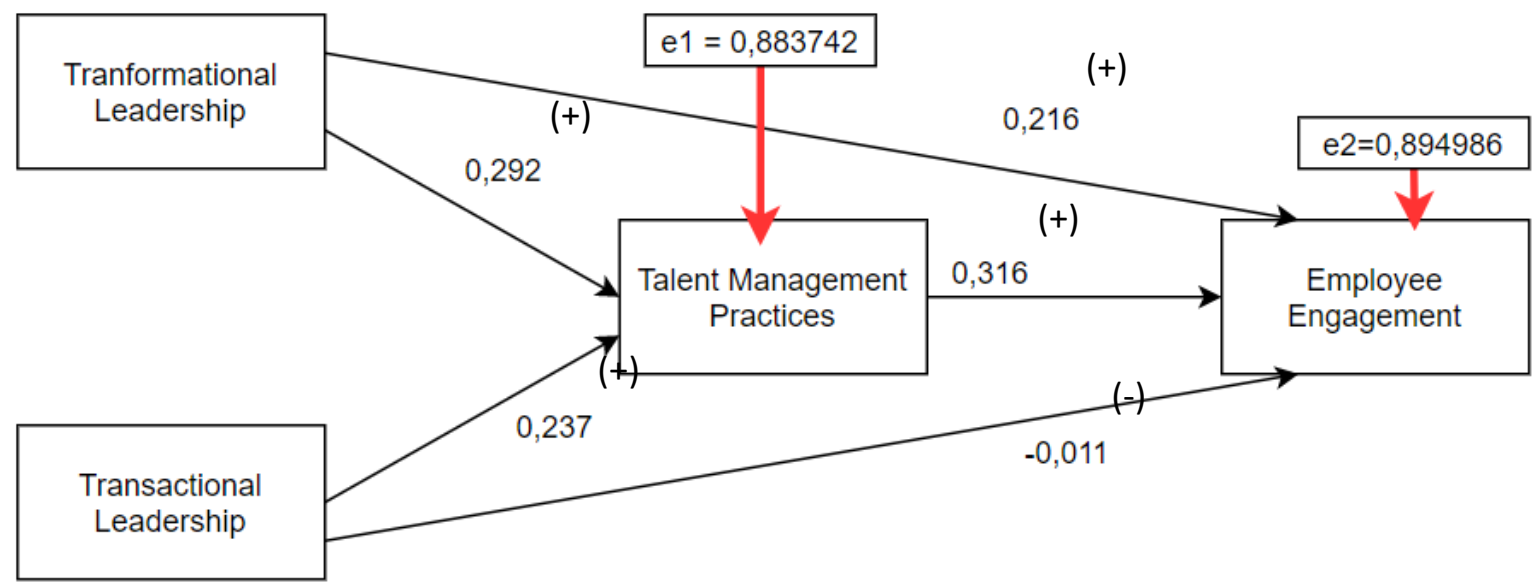

The indirect effect between Transformational Leadership to Employee Engagement, mediated by Talent Management Practices showed a result of beta coefficient of 0,092272 or scored below the direct effect without the mediating variable $(0,092272<0,216)$. There is significant evidence that bothTransformational Leadership and Transactional Leadership to Employee Engagement is mediated by Talent Management Practices (H4 and H5). However the relationship of Transactional Leadership to Employee Engagement is categorized as full mediation by Talent Management Practices. While Transformational Leadership to Employee Engagement, in the other hand, is partial mediated by Talent Management Practices.Full mediation occurs when the relationship between a predictor and an outcome variable becomes nonsignificant after a mediator is entered as an additional predictor. Partial mediation happens when the relationship between a predictor and an outcome is reduced nonetheless remains significant when mediator is also entered as an additional predictor (Hair, 2010). By and large, this signifies that transactional leadership can only influence employee engagement when mediated with talent management, meanwhile transformational leadership can influence employee engagement even without the help of mediating effect from talent management practices.

Figure 3. Hypothesis Findings

\begin{tabular}{cll}
\hline & \multicolumn{1}{c}{ Hypotheses } & \multicolumn{1}{c}{ Findings } \\
\hline H1 & $\begin{array}{l}\text { "Talent Management Practices" positively influence "Employee } \\
\text { Engagement" }\end{array}$ & Hypotheses is accepted \\
\hline H2 & $\begin{array}{l}\text { "Transformational Leadership" positively influence "Talent } \\
\text { Management Practices" }\end{array}$ & Hypotheses is accepted \\
\hline H3 & $\begin{array}{l}\text { "Transactional Leadership" positively influence "Talent Management } \\
\text { Practices" } \\
\text { "Transformational Leadership" positively influence "Employee } \\
\text { Engagement" through mediation of "Talent Management Practices" }\end{array}$ & Hypotheses is accepted \\
H5 & $\begin{array}{l}\text { Hransactional Leadership" positively influence "Employee } \\
\text { Engagement" through mediation of "Talent Management Practices" }\end{array}$ & Hypotheses is accepted \\
\hline
\end{tabular}

This study confirms positive relationship between talent management practices and employee engagement from studies conducted by Sadeli (2012), Sinaga (2017). In the context of this study, talent management practices demonstrated by women leaders shows consistent results in its relationship with employee engagement.Following the explanation from data analysis, it is found that transformational leadership positively influencesemployee engagement both directly and through talent management practices. Additionally, it is also found that women with transfromational leadership style will be able to affect employee engagement more strongly compared to when influencing employee engagement through Talent Managemenet practices. This suggests that transformational leaders do not need to urgently apply talent management practices in order to positively influence employee engagement.

Meanwhile, women leaders demonstrating transactional leadership style can only positively influence employee engagement through talent management practices as mediating variable. Women leaders that adopt transactional leadership style tend to normally have a negativeand insignificant effect employee engagement if not mediated with talent management practices. This can be explained by the fact that transactional leaders are 
built to apply talent management practises because talent management is an inherent part of social exchange and leaders-members transactional acitivity (Saks, 2006; Budiana at al., 2019)

The results also shows new finding on how transactional leadership style and transformational leadership style impact employee engagement through talent management practices compared to previous studies. Transformational leadership style is believed to positively impact employee engagement trough talent management practices (Sadeli, 2012; Sinaga, 2017), howeverSadeli (2012) in his study pointed out that transactional leadership style does notpositively impact employee engagement through talent management practice. This can be explained by the type of respondents involved in this study compared to previousstudies: this study focuses only on organizations that is led women leaders while previous studies does not purposively sample specific gender of the organizations' / companies' leaders. Therefore, in this circumstance, it is concluded that women leaders' touch on talent management practice have the ability to help transactional leaders to engage with employee.

The fact that the data collection was conducted amidst a global pandemic, would also impact on how employees perceive engagement towards women leaders and their leadership styles. Dirani et al (2020) claimed that employees dealing with unimaginable disruptions may go through traumatic experiences and in need of emotional and interpersonal support. In this condition, it would be acceptable that women with transformational leadership style would have a strong influence on employee engagement, with or without practicing talent management policies in the organization. On the other hand, as the COVID-19 pandemic rises economic issues, employees' worries are shifted more concerning finances and tend to be much engaged in reward offerings and risks of unemployment. In this situation, women with transactional leadership would have a strong effect towards employee engagement if it is moderated by talent management practices, which may be the reason this study differs from Sadeli's (2012) findings.

\section{CONCLUSIONS \& IMPLICATIONS}

As the focus on women in leadership position continue to grow, it is important to understand what attributes and supporting mechanism is needed in order to improve women's leadership quality. This research has proven that women in leadership position can positively impact employee's engagement with their jobs and their organization. Women in leadership position are able to increase its suboridnates' engagement by demonstrating clear guidance and explanation on what reward or punishment are expected when jobs are completed(transactional). But then, this study has also discovered that previously mentioned leadeship style must be combined with established talent management to be meaningful on its relationship with employee engagement. Taking all that considerations into account, organization / company and top management needs to provide women leaders with adequate soft and hard infrastructure related to transactional acitivity between subordinates and the women leaders through goals set-up dan career management.

Moreover, when women leaders adopttransformational leadership behavior, company can choose not to aggressively apply talent management practices and might find this as cost efficiency opportunity. This is supported by the fact that women leaders can still manage to positively influence employee engagement even without talent management.

One of the limitation of this study is therestricted number of respondents (117 samples) from various companies and organization in Indonesia. Future researchers on this study are also recommended to explore women leaders behavior with men leaders' on one integrated research. Research of this study should incorporateand develop effort to accelerate the improvement of knowledge in women leaders and employee engagement continuously. Another drawback in this research is the timing of data collection,during COVID-19, which is categorized as a global pandemic, thus has affected on how leaders take approach towards employeesand how employees feel engaged. Lastly, researchers should also put into accountother mediating and/or moderating variables that would help explain relationship between leadership style and employee engagement.

\section{Reference:}

Ashton, C., \& Morton, L. (2005). Managing talent for competitive advantage: Taking a systemic approach to talent management. Strategic HR Review, 4(5), 28-31.

Ayman, R., Korabik, K., \& Morris, S. (2009). Is transformational leadership always perceived as effective? Male subordinates' devaluation of female transformational leaders. Journal of Applied Social Psychology, Vol. 39, 852-879.

Baker, C. (2014). Stereotyping and women's roles in leadership positions. Industrial and Commercial Training, Vol. 46 No 6, pp. 332-337. 
Baron, R. M. and Kenny, D. A. (1986) "The Moderator-Mediator Variable Distinction in Social Psychological Research - Conceptual, Strategic, and Statistical Considerations", Journal of Personality and Social Psychology, Vol. 51(6), pp. 1173-1182.

Bass, B.M. (1985). Leadership and Performance beyond Expectations, The Free Press, New York, NY.

Bass, B.M., dan Avolio, B. (1993). Transformational leadership and perspective. Administrative Science Quarterly, 34, 169-189.

Bedarkar,M.\&Pandita, D. (2014). A study on the drivers of employee engagement impacting employee performance. Procedia - Social and Behavioral Sciences, 133. 106-115. doi:10.1016/j.sbspro.2014.04.174.

Bruckmüller, S., \&Branscombe, N. R. (2010). The glass cliff: When and why women are selected as leaders in crisis contexts. British Journal of Social Psychology, 49(3), 433-451. doi:10.1348/014466609X466594.

Buckingham, M., \& Vosburgh, R. M. (2001). The 21st century human resources function: It's the talent, stupid! Human Resource Planning, 24(4), 17-23

Budiana, I Made, YettiSupriyati, \& Wibowo. (2019). Talent Management Strategy of Employee Engagement. Blue Eyes Intelligence Engineering and Science Publication.

Burns, J. M. (1978). Leadership. New York, NY: Harper \& Row.

Carless, S.A. (1998). Gender diference in transformational leadership: an examination of superior, leader and subordinate perspectives. Sex Roles, Vol. 39 Nos 11/12, pp. 887-902.

Cahill, K. E., McNamara, T. K., Pitt-Catsouphes, M., \&Valcour, M. (2015). Linking shifts in the national economy with changes in job satisfaction, employee engagement and work-life balance. Journal of Behavioral and Experimental Economics, 56, 40-54.

Chao, C.-C. (2011). Climbing the himalayas - a cross-cultural analysis of female leadership and glass ceiling effects in non-profit organizations. Leadership and Organization Development Journal, Vol. 32 No. 8, pp. 760-781.

Chapple, L., and J. E. Humphrey (2014). Does board gender diversity have a financial impact? Evidence using stock portfolio performance. Journal of Business Ethics Vol 122, No.4, pp. 709-723.

Collings, D. G., \&Mellahi, K. (2009). Strategic talent management: A review and research agenda. Human Resource Management Review, 19, 304-313.

Cook, S. (2008). The Essential Guide to Employee Engagement: Better Business Performance Through Staff Satisfaction. London, UK: Kogan Page Limited.

Collings, D.G., Mellahi, K.. (2009). Strategic talent management: areview and research agenda. Hum. Resour. Manage. Rev. 19 (4),304-313.

Cuadrado, I., Navas, M., Molero, F., Ferrer, E., \& Morales, J. F. (2012). Gender differences in leadership styles as a function of leader and subordinates' sex and type of organization: Gender differences in leadership styles. Journal of Applied Social Psychology, Vol.42, pp. 3083-3113.

Davies, B. \& Davies, B.J. (2010). Talent management in academies. International Journal of Educational Management, 24 (5).418 - 426. doi:10.1108/09513541011055983.

De Cremer, D. and van Knippenberg, D., (2005). Cooperation as a function of leader self-sacrifice, trust and identification. Leadership and Organization Development Journal, Vol. 26 No. 5, pp. 355-369.

Dirani, K. M., Abadi, M., Alizadeh, A., Barhate, B., Garza, R. C., Gunasekara, N., Ibrahim, G., \&Majzun, Z. (2020). Leadership competencies and the essential role of human resource development in times of crisis: a response to Covid-19 pandemic. Human Resource Development International, 1-15. doi:10.1080/13678868.2020.1780078

Eagly, A. H., Wood, W., \&Diekman, A. B. (2000). Social role theory of sex differences and similarities: A current appraisal. In T. Eckes, \& H. M. Trautner (Eds.), The developmental social psychology of gender (pp. 123-174). Erlbaum.

Eagly, A. H. (2013). Women as leaders: Leadership style versus leaders' values and attitudes. In R. J. Ely \& A. J. C. Cuddy (Eds.), Gender and work: Challenging conventional wisdom (pp. 4-11). Boston, MA: Harvard Business School Press.

Erturk, A. (2007). Increasing organizational leadership behaviours of turkish academicians, mediating role of trust in supervisor on the relationship between organizational justice and citizenship behaviours. Journal of Managerial Psychology, Vol. 22 No. 3

Fernandes, E. \& Cabral-Cardoso, C. (2003). Gender asymmetries and the manager stereotype among management studies. Women in Management Review, 18. 77-87.

Gallup, Inc. (2016). Women in America : Work and Life Well-Lived. United States of America: Author.

Gipson, A.N., Pfaff, D.L., Mendelsohn, D.B., Catenacci L.T., Burke, W.W., (2017). Women and Leadership: Selection, Development, Leadership Style, and Performance. The Journal of Applied Behavioral Science, Vol. 53 No. 1, pp. 32-65 
Hair, J.F, Black W.C., Babin, B.J., Anderson, R.E., Tatham, R.L. (2014). Multivariate data analysis, $7^{\text {Th }}$ Edition. New Jersey, USA : Pearson International Edition.

Hansen,A., Byrne, Z., \&Kiersch,C. (2013). How interpersonal leadership relates to employee engagement. Journal of Managerial Psychology, 29 (8). 963-972.

J., A. (2014). Determinants of employee engagement and their impact on employee performance. International Journal of Productivity and Performance Management, 63(3), 308-323. doi:10.1108/ijppm-01-2013-0008.

Johnson, S. K., Murphy, S. E., Zewdie, S., \& Reichard, R. J. (2008). The strong, sensitive type: Effects of gender stereotypes and leadership prototypes on the evaluation of male and female leaders. Organizational Behavior and Human Decision Processes, Vol. 106, No. 1, pp. 39-60.

Kahn, W.A. (1990). Psychological conditions of personal engagement and disengagement at work. The Academy of Management Journal, 33(4). 692-724. doi:http://www.jstor.org/stable/256287.

Kim, C., Lee, J. \& Rhee, J. (2015). The Role of Leader's Talent Management Ability in Relations between Leadership Styles and Organizational Effectiveness. Canadian Center of Science and Education.

Koenig, A.M., Eagly, A.H., Mitchell, A.a. and Ristikari, T. (2011). Are leader stereotypes masculine? A Metaanalysis of three research paradigms. Psychological Bulletin, 137(4). 616-642.

Lowe, K.B., K., Kroeck, G.K., Sivasubramaniam, N. (1996). Effectiveness correlates of transformational and transactional leadership: A meta-analytic review of the MLQ literature. The Leadership Quarterly. Vol. 7, No. 3, pp. 385-425.

Lyness, K.S., and Heilman, M.E. (2006). When fit is fundamental: performance evaluations and promotions of upper-level female and male managers. Journal of Applied Psychology, Vol. 91 No. 4, pp. 777-85.

May, D.R., Gilson, R.L., Harter, L.M. (2004). The psychological conditions of meaningfulness, safety and availability and the engagement of the human spirit at work. Journal of Occupational and Organizational Psychology, 77.11-37. doi:10.1348/096317904322915892.

McKinsey \& Company (2018). The Power of Parity: Advancing Women's Equality in Asia Pacific. Retrieved from

https://www.mckinsey.com/ /media/McKinsey/Featured\%20Insights/Asia\%20Pacific/The\%20power\%2 0of $\% 20$ parity $\% 20$ Advancing $\% 20$ womens $\% 20$ equality $\% 20$ in $\% 20$ Indonesia/The-power-of-parity-

Mohammed, A. (2015). The impact of talent management on employee engagement, retention and value addition in achieving organizational performance. International Journal of Core Engineering \& Management, 1(12). 142-152.

Mojza, E.J., Sonnentag, S. and Bornemann, C. (2011). Volunteer work as a valuable leisure-time activity: a day level study on volunteer work, non-work experiences and well-being at work. Journal of Occupational and Organizational Psychology, Vol. 84 No. 1, pp. 123-152.

Noe, A.R, Hollenbeck, J.R., Gerhart, B., \& Wright, P.M. (2015). Human resource management (10 ${ }^{\text {th }}$ Ed.). United States of America: McGraw-Hill Education.

Pasaribu, P. (2017). Female directors and firm performance: Evidence from UK listed firms. Gadjah Mada International Journal of Business, 19 (2). 45-166.

Parveen, S., Tariq, A. (2014). Leaderhip Style, Gender, and Job Satisfaction: A Situational Leadership Approach. International Journal of Science and Research, Vol.3, No. 12.

Popli, S. \& Rizvi, I. (2016). Drivers of employee engagement: The role of leadership style. Global Business Review, 17(4). 965-979. doi: 10.1177/0972150916645701.

Qadir, M. (2019). The Challenges of Women Leadership and Management in India. Department. Department of Sociology Babasaheb Bhimarao Ambedkar University. Lucknow.

Raes, E., Decuyper, S., Lismont, B., Van den Bossche, P., Kyndt, E., Demeyere, S. and Dochy, F. (2013). Facilitating team learning through transformational leadership. Instructional Science, Vol. 41, No. 2, pp. 287-305.

Rosener, J.B., (1990). Ways Women Lead. In P.H. Werhane, M. Painter-Morland (Eds.), Leadership, Gender, and Organization Issues in Business Ethics, Vol 27 (pp.19-29). Springer Science Business Media B.V, 2011.

Rosette, A., and Tost, L., (2010). Agentic women and communal leadership: how role prescriptions confer advantage to top women leaders. Journal of Applied Psychology, Vol. 95 No. 2, pp. 221-235.

Rothmann, S. (2016). Employee engagement. In The Wiley Blackwell handbook of the psychology of positivity and strengths-based approaches at work. https://doi.org/10.1002/9781118977620.ch18.

Rowold, J., and Schlotz, W., (2009). Transformational and Transactional Leadership and Followers' Chronic Stress. Kravis Leadership Institute, Leadership Review, Vol. 9, Spring 2009, pp. 35-48.

Rudman, L.A., Moss-Racusin, C.A., Glick, P., Phelan, J.E., (2012). Chapter Four - Reaction to Vanguards: Advances in Backlash Theory. Advances in Experimental Social Psychology, Vol 45, No.1, pp. 167-227. 
Sadeli, J. (2011). Leadership-driven model on employee engagement: A social exchange perspective. University of Indonesia Dissertation, Jakarta.

Sadeli, J. (2012). The influence of leadership, talent management, organizational culture and organizational support on employee enagagement. International Research Journal of Business Studies, 5 (3).

Saks, A. M. (2006). Antecedents and consequences of employee engagement. Journal of Managerial Psychology, 21(7). 600-610. doi: 10.1108/026839406106901.

Saks, A. M. (2019). Antecedents and consequences of employee engagement revisited. Journal of Organizational Effectiveness: People and Performance. doi:10.1108/joepp-06-2018-0034

Schiemann, W.A. (2009). Reinventing talent management: How to maximize performance in the new marketplace. Hoboken, New Jersey: John Wiley and Sons, Inc.

Schaufeli, W. B., Salanova, M., González-Romá, V., \& Bakker, A. B. (2002). The measurement of engagement and burnout: A two-sample confirmatory factor analytic approach. Journal of Happiness Studies, 3, 71-92.

Sharif, K. (2018). Transformational leadership behaviors of women in a socially dynamic environment. International Journal of Organizational Analysis, Vol. 12 No.1.

Shinbrot, X.A., Wilkins, K., Gretzel, U., Browser, G., (2019). Unlocking women's sustainability leadership potential: Perceptions of contributions and challenges for women in sustainable development. World Development, Vol. 19, No.1, 120-132.

Sinaga,

$$
\text { J.D, Satrya, }
$$

A.

(2017).

Pengaruhperilakupemimpinterhadapketertarikanpekerjadalammenciptakankeunggulandayasaingperusahaan yang berkesinambungan (StudiKasus pada PT Perusahaan Gas Negara (Persero) TBK). University of Indonesia Thesis, Jakarta.

Smith, D.N, Suby-Long, S., (2019). Women Leaders and Narratives: The Power of Reflecting on Purpose and Career. Advancing Women in Leadership, Vol. 39, No. 4, pp. 1-11.

Sorenson, S. (2013). How Employee Engagement Drives Growth. Retrieved from: https://www.gallup.com/workplace/236927/employee-engagement-drives-growth.aspx

Stahl, G.K., Björkman, I., Farndale, E., Morris, S.S., Paauwe, J.,Stiles, P., Trevor, J., Wright, P. (2012). Six principles of effective global talent management. MIT Sloan Manage. Rev. 53, 25---32.

Vinkenburg, C.J., van Engen, M.L., Eagly, A.H. and Johannensen-Schmidt, M.C. (2011). An exploration of stereotypical beliefs about leadership styles: is transformational leadership a route to women's promotion?,Leadership Quarterly, Vol. 22, No. 1, pp. 10-21.

Vongalis-Macrow, A. (2016). It's About the Leadership: The Importance of Women Leaders Doing Leadership for Women. NASPA Journal About Women in Higher Education. Doi:10.1080/19407882.2015.1114953

Walker, J. W., \&Larocco, J. M. (2002). Talent pools: The best and the rest. Human Resource Planning, 25(3), $12-14$

Appendix: Research Variables, Operationalization, and Indicators (adopted from Bass and Avolio, 1993; Sadeli, 2011; Saks, 2006)

\begin{tabular}{|c|c|c|c|}
\hline Variable & Operational Definition & $\begin{array}{c}\text { Cronbach's } \\
\text { Alpha }\end{array}$ & Indicator \\
\hline \multirow[t]{3}{*}{$\begin{array}{l}\text { Transformational } \\
\text { Leadership - IV } \\
1\end{array}$} & \multirow[t]{3}{*}{$\begin{array}{lccc}\text { Kepemimpinan } & \text { yang } & \text { menekankanpengembanganmotivasi } & \text { dan } \\
\text { memprioritaskanpertimbanganpreferensitiaptiapindividupengikutnya (Bass, 1985) } & \end{array}$} & \multirow[t]{3}{*}{0.924} & $\begin{array}{l}\text { Idealized } \\
\text { influence }\end{array}$ \\
\hline & & & $\begin{array}{l}\text { Intellectual } \\
\text { stimulation }\end{array}$ \\
\hline & & & $\begin{array}{l}\text { Individual } \\
\text { consideration }\end{array}$ \\
\hline
\end{tabular}




\begin{tabular}{|c|c|c|c|}
\hline & & & $\begin{array}{l}\text { Inspirational } \\
\text { motivation }\end{array}$ \\
\hline \multirow[t]{3}{*}{$\begin{array}{l}\text { Transactional } \\
\text { Leadership - IV } \\
2\end{array}$} & \multirow[t]{3}{*}{$\begin{array}{l}\text { Kepemimpinan yang menekankansistempertukaranantarapemimpin dan } \\
\text { anggotadimanapemimpinakanmemberikanhadiahataumendisiplinkananggotanyabergantung } \\
\text { pada performaanggotanya. (Bass, 1985) }\end{array}$} & \multirow[t]{3}{*}{0.716} & $\begin{array}{l}\text { Contingent } \\
\text { Reward }\end{array}$ \\
\hline & & & $\begin{array}{l}\text { Active } \\
\text { management } \\
\text { by exception }\end{array}$ \\
\hline & & & $\begin{array}{l}\text { Passive } \\
\text { management } \\
\text { by exception }\end{array}$ \\
\hline \multirow[t]{3}{*}{$\begin{array}{l}\text { Talent } \\
\text { Management - } \\
\text { MV1 }\end{array}$} & & \multirow[t]{3}{*}{0.926} & $\begin{array}{l}\text { Performance } \\
\text { Management }\end{array}$ \\
\hline & & & $\begin{array}{l}\text { People } \\
\text { Development }\end{array}$ \\
\hline & & & $\begin{array}{l}\text { Succession } \\
\text { Planning }\end{array}$ \\
\hline $\begin{array}{l}\text { Employee } \\
\text { Engagement } \\
\text { DV }\end{array}$ & $\begin{array}{l}\text { sejauh mana karyawansepenuhnyaterlibatdalampekerjaanmereka } \\
\text { kekuatankomitmenmerekaterhadappekerjaan dan perusahaanmereka }\end{array}$ & 0.854 & $\begin{array}{l}\text { Job } \\
\text { Enagagement }\end{array}$ \\
\hline
\end{tabular}




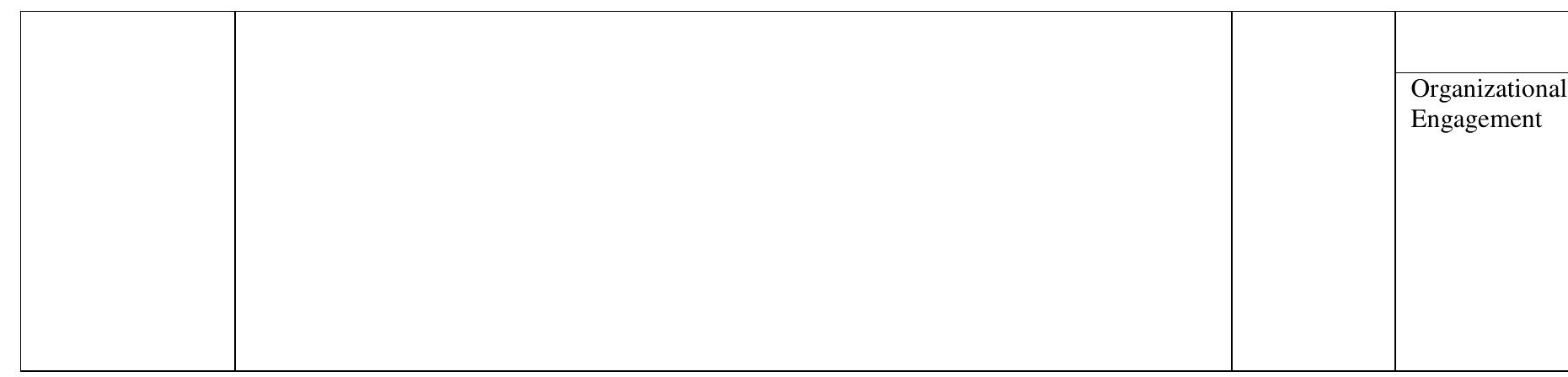

